\title{
OPEN Positive effects of COVID-19 lockdown on air quality of industrial cities (Ankleshwar and Vapi) of Western India
}

\begin{abstract}
Ritwik Nigam¹, Kanvi Pandya², Alvarinho J. Luis ${ }^{3}$, Raja Sengupta $^{4}$ \& Mahender Kotha ${ }^{1 凶}$
On January 30, 2020, India recorded its first COVID-19 positive case in Kerala, which was followed by a nationwide lockdown extended in four different phases from 25th March to 31st May, 2020, and an unlock period thereafter. The lockdown has led to colossal economic loss to India; however, it has come as a respite to the environment. Utilizing the air quality index (AOI) data recorded during this adverse time, the present study is undertaken to assess the impact of lockdown on the air quality of Ankleshwar and Vapi, Gujarat, India. The AQI data obtained from the Central Pollution Control Board was assessed for four lockdown phases. We compared air quality data for the unlock phase with a coinciding period in 2019 to determine the changes in pollutant concentrations during the lockdown, analyzing daily $\mathrm{AQI}$ data for six pollutants $\left(\mathrm{PM}_{10}, \mathrm{PM}_{2.5}, \mathrm{CO}, \mathrm{NO}_{2}, \mathrm{O}_{3}\right.$, and $\left.\mathrm{SO}_{2}\right)$. A meta-analysis of continuous data was performed to determine the mean and standard deviation of each lockdown phase, and their differences were computed in percentage in comparison to 2019; along with the linear correlation analysis and linear regression analysis to determine the relationship among the air pollutants and their trend for the lockdown days. The results revealed different patterns of gradual to a rapid reduction in most of the pollutant concentrations $\left(\mathrm{PM}_{10}, \mathrm{PM}_{2.5}, \mathrm{CO}, \mathrm{SO}_{2}\right)$, and an increment in ozone concentration was observed due to a drastic reduction in $\mathrm{NO}_{2}$ by $80.18 \%$. Later, increases in other pollutants were also observed as the restrictions were eased during phase-4 and unlock 1. The comparison between the two cities found that factors like distance from the Arabian coast and different industrial setups played a vital role in different emission trends.
\end{abstract}

The novel coronavirus termed as COVID-19 by World Health Organization (WHO), first emerged in late December 2019 in Wuhan, China. In early March 2020, due to its rapid spread, the WHO declared COVID-19 as a pandemic. By July 8, 2020, it spread to more than 210 countries worldwide, infecting over 11 million people and causing 539,026 mortalities ${ }^{1}$. As COVID-19 is highly transmissible, along with a high mortality rate ${ }^{2}$, countries worldwide have taken various precautionary measures, such as large scale COVID-19 screening tests, quarantine, social distancing, wearing of mask, sanitization of hands, etc ${ }^{3}$. This led to 2-4 weeks of regional lockdowns to limit the spread of the virus, all of which have subsequently restricted economic activities around the world leading to different regional repercussions ${ }^{4}$.

In India, a student who had returned from Wuhan, China, was the first COVID-19 positive case recorded on January 30 in Kerala ${ }^{5}$. India took unprecedented measures to contain the infection from across borders and within its territory. International travel and non-essential traveling visas were suspended on March 13, 2020. The Indian railways shut down its operations on March 23, 2020, for the first time in its history spanning over 167 years. A 21-day nationwide lockdown phase-1 was enforced from March 25 to April 14, which was extended further until May 31, 2020. Divided into different phases, the lockdown was marked by increasing relaxations in socio-economic activities in less infected regions. The timeline of the various COVID-19 lockdown phases in India ${ }^{6}$ is depicted in Fig. 1.

\footnotetext{
${ }^{1}$ School of Earth, Ocean and Atmospheric Sciences (SEOAS), Goa University, Taleigao Plateau, Goa 403206, India. ${ }^{2}$ Department of Geography, Faculty of Science, The Maharaja Sayajirao University of Baroda, Fatehgunj, Vadodara 390002, India. ${ }^{3}$ Earth System Science Organization-National Centre of Polar and Ocean Research, Ministry of Earth Science, Govt. of India, Headland Sada, Goa 403804, India. ${ }^{4}$ Department of Geography \& McGill School of Environment, McGill University, Montreal, OC H3A0B9, Canada. ${ }^{\circledR}$ email: mkotha@unigoa.ac.in
} 


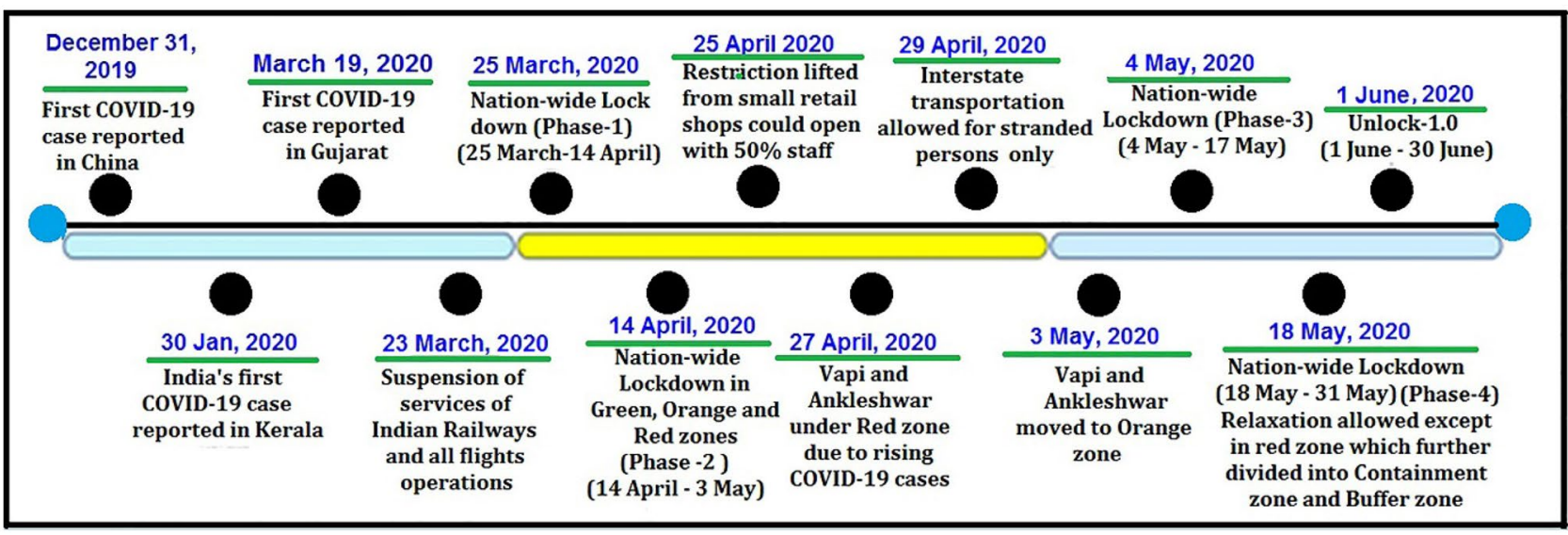

Figure 1. COVID-19 timeline of India. (Source: Ministry of Home Affairs, Govt. of India).

While the socio-economic devastation due to COVID-19 has been colossal around the world, which required "a wartime" plan from every corner of the world ${ }^{7}$ it has also come as the silver lining for the environment ${ }^{8}$. The United Nations Environment Program chief Inger Andersen believes these environmental changes are temporary ${ }^{7}$, as the global environment had a small respite before industrial activities resumed since February 2020. Recent studies have reported improvement in air quality due to restrictions placed upon industrial activities during the lockdown. Climate scientists have indicated that greenhouse gaseous (GHGs) concentration could drop to levels not seen since World War II. Highly industrialized cities located in cold climate zones observed a higher reduction in air pollution'.

Lockdown in various countries viz., France, Germany, Italy, Spain, and China led to shutting down of power plants, transportation, and other industries which resulted in drastic decrease in concentration levels of GHGs, $\mathrm{NO}_{2}, \mathrm{PM}_{2.5}, \mathrm{PM}_{10}$ and $\mathrm{CO}$ but spikes in ozone concentration simultaneously, primarily in Europe and large Chinese cities ${ }^{3,10-14}$. The air quality changes during COVID-19 lockdown over the Yangtze River Delta Region suggest that the reduced human activity and industrial operations lead to significant reduction in $\mathrm{PM}_{2.5}, \mathrm{NO}_{2}$, and $\mathrm{SO}_{2}{ }^{14}$. Significant improvement in air quality, as evidenced from the reduction in Particulate Matter, NOx, SO2 and CO, during the COVID19 lockdown period was observed in the Hangzhou megacity ${ }^{15}$. Reduction of $\mathrm{NO}_{2}(49 \%)$, and CO (37\%) concentrations in the USA during lockdown were positively correlated with higher population density ${ }^{3}$. The impact of the measures on the air quality is discussed ${ }^{16}$ for the city of Rio de Janeiro, Brazil by comparing the particulate matter, carbon monoxide, nitrogen dioxide and ozone concentrations during the partial lockdown with those of the same period of 2019 and also with the weeks prior to the virus outbreak. A positive impact of the social distancing measures is reported ${ }^{17}$ on the concentrations of the three main primary air pollutants $\left(\mathrm{PM}_{10}, \mathrm{NO}_{2}\right.$ and $\left.\mathrm{CO}\right)$ of the São Paulo and Rio the Janeiro, the two most populated cities, wherein, the $\mathrm{CO}$ levels showed the most significant reductions (up to 100\%) which was related to light-duty vehicular emissions. Changes in levels of some air pollutants due to a set of rapid and strict countermeasures limiting population's mobility and prohibiting almost all avoidable activities was evaluated in the in Sale city (NorthWestern Morocco ${ }^{18}$. Barcelona city was assessed ${ }^{19}$ for air quality using a remote sensing dataset provided by ESA's Tropospheric monitoring instrument (TROPOMI) along with local air quality monitoring data to assess differences in air quality during the lockdown and one month before the lockdown. The observed reductions were $31 \%$ and $51 \%$ in $\mathrm{NO}_{2}$ and $\mathrm{PM}_{2.5}$, respectively, due to lockdown. The National Aeronautics and Space Agency (NASA), using the TROPOMI sensor, observed a reduction of $10-30 \%$ in Nitrogen Dioxide $\left(\mathrm{NO}_{2}\right)$ in central and eastern China during early $2020^{20} .27 \%$ reduction was observed in nitrogen oxides concentration in comparison to the last five years, and non-uniform trends in $\mathrm{O}_{3}$ concentrations during the lockdown in California basin region $^{21}$. Black carbon reduction due to the lockdown imposed restricted anthropogenic activities is observed in Hangzhou city of China ${ }^{22}$. A reduction of $43 \%$ and $31 \%$ in $\mathrm{PM}_{10}$ and $\mathrm{PM}_{2.5}$, while a $17 \%$ increment in $\mathrm{O}_{3}$ concentration during the lockdown period and past 4-year values for different regions of India has also been reported ${ }^{23}$.

The common air pollutants in cities and industrial towns are $\mathrm{NO}_{2}, \mathrm{SO}_{2}, \mathrm{PM}_{10}$, which are responsible for cardiovascular and respiratory diseases ${ }^{24,25}$. The primary sources of these pollutants are vehicular exhaust, road dust, and mainly metal processing industries ${ }^{26,27}$. The majority of the health benefits were observed with the reduction in $\mathrm{NO}_{2}$ in 31 provincial capital cities in China ${ }^{12}$. Continuous degradation of air quality in some of the Indian metropolitan cities (New Delhi, Mumbai, Kolkata, Chennai), that often exceed the standards set by WHO and Central Pollution Control Board (CPCB), India, cemented their regular presence in the list of top 20 polluted cities of the world ${ }^{28-30}$. The Ministry of Earth, Forest, and Climate change (MoEFC) under its National Clean Air Programme (NCAP) launched a five-year action plan in 2019 to reduce by $30 \%$ the nationwide concentration of particulate matter ${ }^{31}$. Due to the mandatory lockdown imposed across the country, 88 Indian cities have observed a drastic reduction in air pollution ${ }^{23}$.

Gujarat, which is the industrial state in western India, observed a significant reduction in major air pollutants between the lockdown period (March 25 to April 20,2020) mainly due to restrictions on traffic and slowdown of production at factories ${ }^{32}$. According to the CPCB-AQI database, air pollution reduction occurred merely in four days since the lockdown ${ }^{33}$. In Vapi, $\mathrm{PM}_{10}, \mathrm{PM}_{2.5}, \mathrm{NO}_{2}, \mathrm{SO}_{2}$ are the major air pollutants significantly emitted by transport vehicles and industrial ${ }^{34}$. 


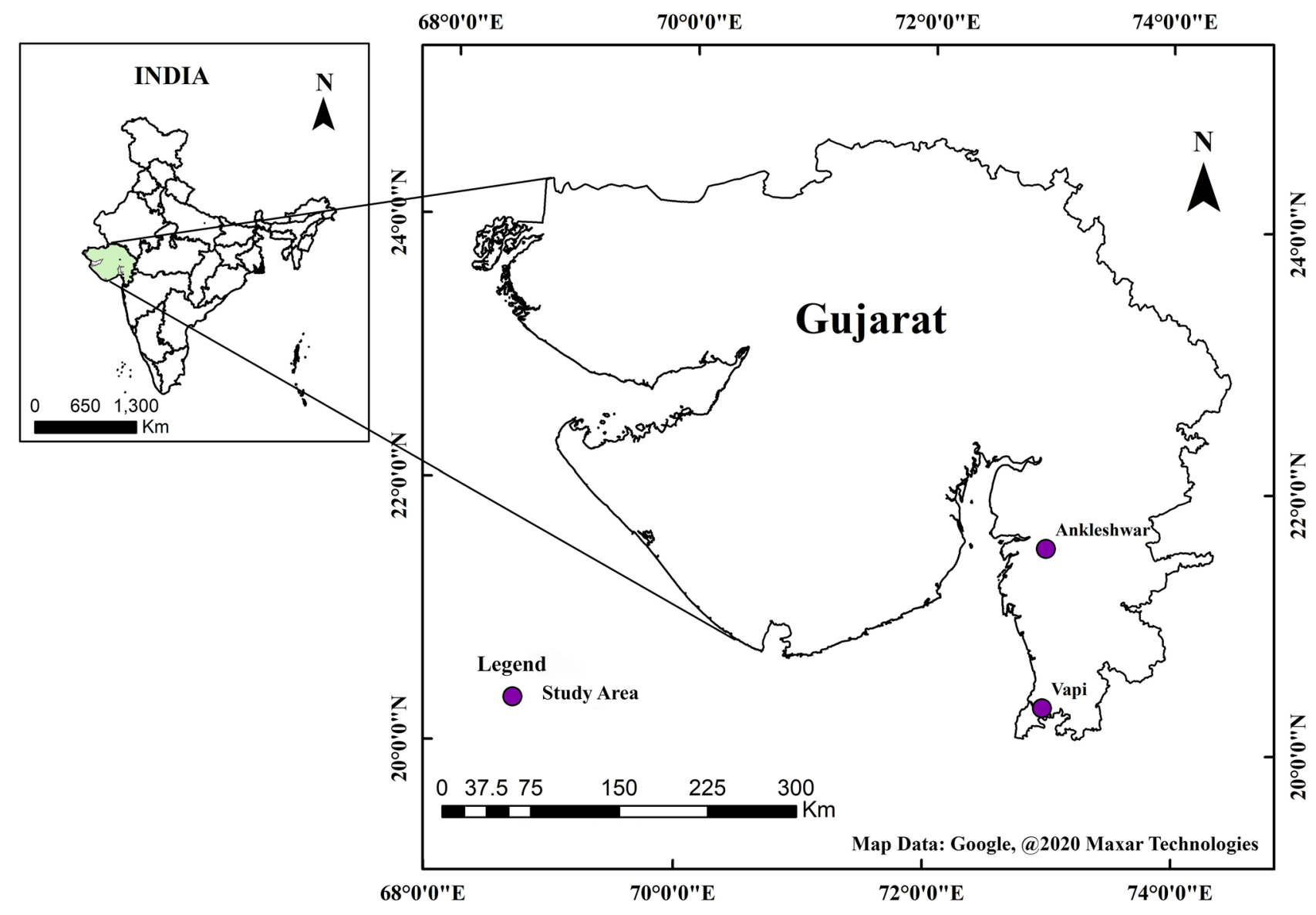

Figure 2. The locations of industrialized cities Ankleshwar and Vapi in Gujarat, India.

This present study is undertaken to determine the differences in concentration of six pollutants $\left(\mathrm{PM}_{10}, \mathrm{PM}_{2.5}\right.$, $\mathrm{CO}, \mathrm{NO}_{2}, \mathrm{O}_{3}$, and $\mathrm{SO}_{2}$ ) during the lockdown period (March 25 to June 15, 2020) with the comparable period in 2019, to assess the impact of lockdown on air quality in cities Vapi and Ankleshwar of Gujarat, India.

\section{Study area}

Ankleshwar is located at $21.62^{\circ} \mathrm{N}, 73.01^{\circ} \mathrm{E}$ is a municipality under Bharuch district juridiction in Gujarat, India (Fig. 2). It is located in the south Gujarat region in between Ahmedabad-Mumbai industrial corridor on the southern banks of lower reaches of the Narmada river. The city has plain topography with an average elevation of $15 \mathrm{~m}$ above mean sea level. The climate of South Gujarat region is mainly influenced by the Arabian Sea. Premonsoon showers announce the arrival of monsoon only in late june, with hot summer months (March to June), heavy to moderate monsoon rain (July to September), and moderate winter months (November to February). Ankleshwar Gujarat Industrial Development Corporation is spread over an area of 1600 hectares and houses more than 2000 industries with over 1500 chemical plants producing pharmaceuticals, paints, and pesticides.

Vapi, located at $20.3893^{\circ} \mathrm{N} 72.9106^{\circ} \mathrm{E}$, is a municipality under the Valsad district in Gujarat, India (Fig. 2), located at the southernmost tip of Gujarat between Surat in the north and Mumbai (Maharashtra) in the South. Sandwiched between the union territories of Daman \& Diu and Dadar and Nagar Haveli, the city is $7 \mathrm{~km}$ inland from the Arabian sea; thus, experiences coastal tropical weather with annual rainfall ranging from 100 to 120 in. starting from late June and go on till September ${ }^{35}$. Vapi is also a major industrial hub, $160 \mathrm{~km}$ south of Ankleshwar, predominantly housing chemical plants that account for $70 \%$ of the total industries in the city. Other industries are packaging, paper, plastics, and rubber. Vapi is also known as a 'Paper hub' as it houses the best quality Kraft paper manufacturing units in India. The city has the largest Common Effluent Treatment Plant (or CETP) in Asia ${ }^{36}$. However, due to ever-increasing air and water pollution, Vapi and Ankleshwar are the most industrial clusters of Gujarat (especially Vapi regularly makes it to the list of the most polluted cities in India ${ }^{37}$.

\section{Material and method}

The Government of India, in 2016, under its 'Swacch Bharat Mission,' launched the 'National Air Quality Index' $(\mathrm{NAQI})^{38}$. The NAQI bulletin is published daily by the Central Pollution Control Board (CPCB). There are two different techniques to monitor air quality; online monitoring network and manual monitoring network. The online monitoring network is more reliable than its counterpart as it provides pollutant concentration data almost in real-time. The automatic monitoring network AQI consists of monitoring of eight major parameters (Table 1) 


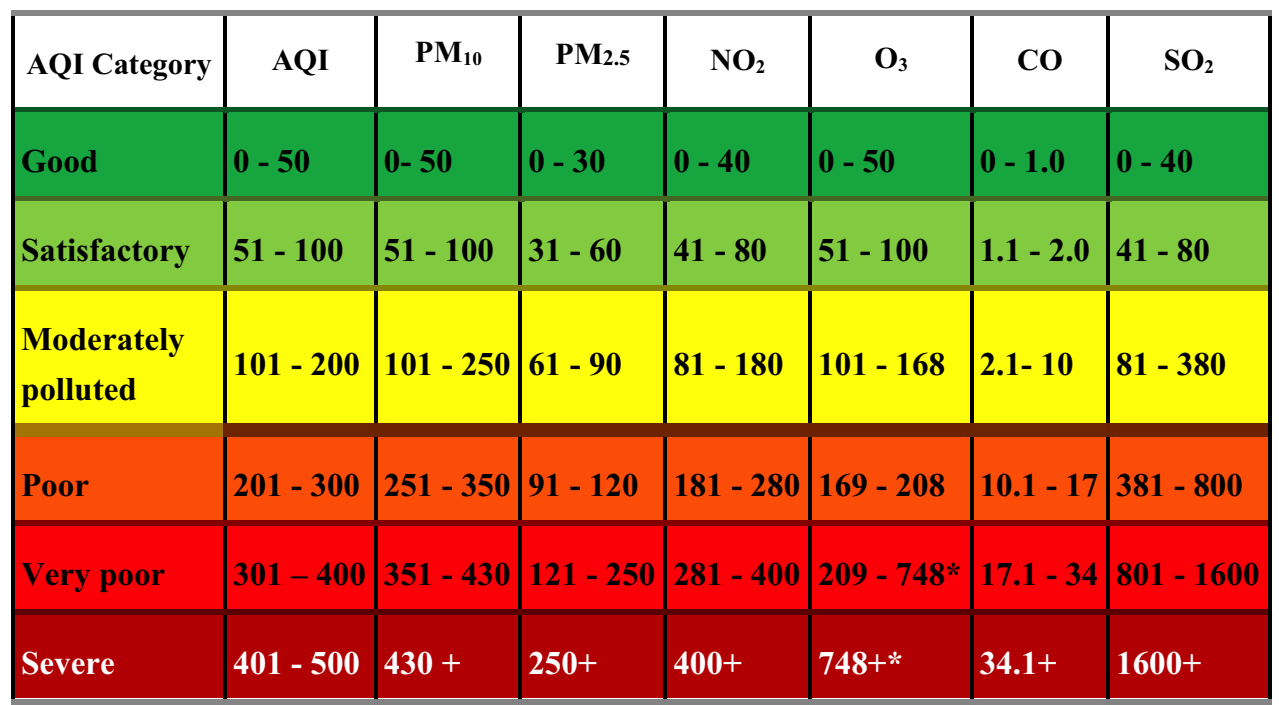

Table 1. Breakpoints for AQI Scale 0-500 (all pollutants are in units of $\mu \mathrm{g} / \mathrm{m}^{3}$ and CO is expressed in units of $\left.\mathrm{mg} / \mathrm{m}^{3}\right) .{ }^{\star}$ Hourly monitoring Source: Central Pollution Control Board ${ }^{39}$.

to compute the index value, while the manual monitoring network AQI considers mainly $\mathrm{PM}_{10}, \mathrm{SO}_{2}$, and $\mathrm{NO}_{2}$ pollutants ${ }^{39}$. Under the NAQI, the averaging time for pollutants such as: $\mathrm{PM}_{2.5}, \mathrm{PM}_{10}, \mathrm{NO}_{2}, \mathrm{SO}_{2}, \mathrm{~Pb}$, and $\mathrm{NH}_{3}$ is 24-h whereas, $\mathrm{O}_{3}$ and $\mathrm{CO}$ have the averaging time of 1-h. Except for $\mathrm{CO}$ which is measured in $\mathrm{mg} / \mathrm{m}^{3}$, all other seven pollutants are measured in $\mu \mathrm{g} / \mathrm{m}^{3}$.

The breakpoint table of daily NAQI provides numeric values and color codes. The color codes are dependent on the numeric values: the AQI value between 0 and 50 suggests it as good with minimal impact on health and shown by dark green color code. Likewise, values in the range of 51-100 are termed as satisfactory (light green) wherein minor breathing discomfort occurs to sensitive people, range of 101-200 is termed as moderately polluted (yellow), range of 201-300 is termed as Poor (orange), values in the range of 301-400 are termed as very poor (light red) and, values in the range of $401-500$ as listed as severe (dark red) ${ }^{40}$.

The objective of the NAQI is to assist with monitoring of daily ambient air quality and generate a multitemporal database. The AQI keeps vigil on air pollutant concentration levels to determine their violation above the permissible limits of ambient air quality in the given area. 200 AQI stations are continuously monitoring air quality across the country ${ }^{40}$. All India AQI monitoring consists of several organizations like the CPCB, the State Pollution Control Boards (SPCB), National Environmental Engineering Research Institute (NEERI), Nagpur, and pollution control committees. The CPCB coordinates with all these agencies to ensure the uniformity, consistency of the air quality data, and provide technical and financial support to them for operating the monitoring stations $^{38}$.

The mathematical equation for calculating sub-indices of AQI is as follows:

$$
\mathrm{Ip}=\left(\frac{\mathrm{IHI}-\mathrm{ILO}}{\mathrm{BPHI}-\mathrm{BPLO}} \times(\mathrm{CP}-\mathrm{BPLO})\right)+\mathrm{ILO},
$$

where $I_{P}$ is AQI for pollutant " $P$ " (Rounded to the nearest integer), $C_{P}$ the actual ambient concentration of pollutant " $\mathrm{P}$ ", $\mathrm{B}_{\mathrm{PHI}}$ the upper-end breakpoint concentration that is greater than or equal to $\mathrm{C}_{\mathrm{P}} \mathrm{B}_{\mathrm{PLO}}$ the lower end breakpoint concentration that is less than or equal to $\mathrm{C}_{\mathrm{P}} \mathrm{I}_{\mathrm{LO}}$ the sub-index or AQI value corresponding to $\mathrm{B}_{\mathrm{PLO}}$, $\mathrm{I}_{\mathrm{HI}}$ the sub-index or AQI value corresponding to $\mathrm{B}_{\mathrm{PHI}}$.

The total lockdown duration of 84 days was divided into five different periods based on different nationwide lockdown phases imposed by the Government of India to compare with 2019. The five phases of lockdown (four lockdowns and one unlock-1.0) had different sets of rules and restrictions for the general public. Phase- 1 of the nationwide lockdown lasted from March 25 to April 14, 2020, with complete restrictions on economic activities. During the second lockdown phase which lasted for 19 days starting from April 15 to May 3, various parts of the cities were color-coded into green, orange, and red zones based on the number of COVID-19 positive cases; the red zones indicating rapidly rising cases had total lockdown, orange zones (moderately rising cases) were provided with some relaxation, and the green zone (low positive cases) had least restrictions among them. The third phase lasted for 14 days (May 4-17, 2020), whereas, the fourth phase (labeled as the last period of nationwide lockdown with change from the green, orange and red zones to the containment zone and buffer zone) was extended from May 18-31, 2020. The unlock 1.0 (referred to in the study as 'phase-5') commenced on June 1,2020 , with several restrictions uplifted everywhere, except in the containment zones. The differences in the magnitude of restrictions imposed during various lockdown phases had an indirect impact on the fluctuation in the air pollutant level due to the restarting of several economic activities in the cities.

The concentration values of six air pollutants $\left(\mathrm{PM}_{10}, \mathrm{PM}_{2.5}, \mathrm{NO}_{2}, \mathrm{O}_{3}, \mathrm{CO}\right.$, and $\left.\mathrm{SO}_{2}\right)$ during the nationwide lockdown period in 2020 and for the similar period of 2019 were downloaded from the daily NAQI data portal 


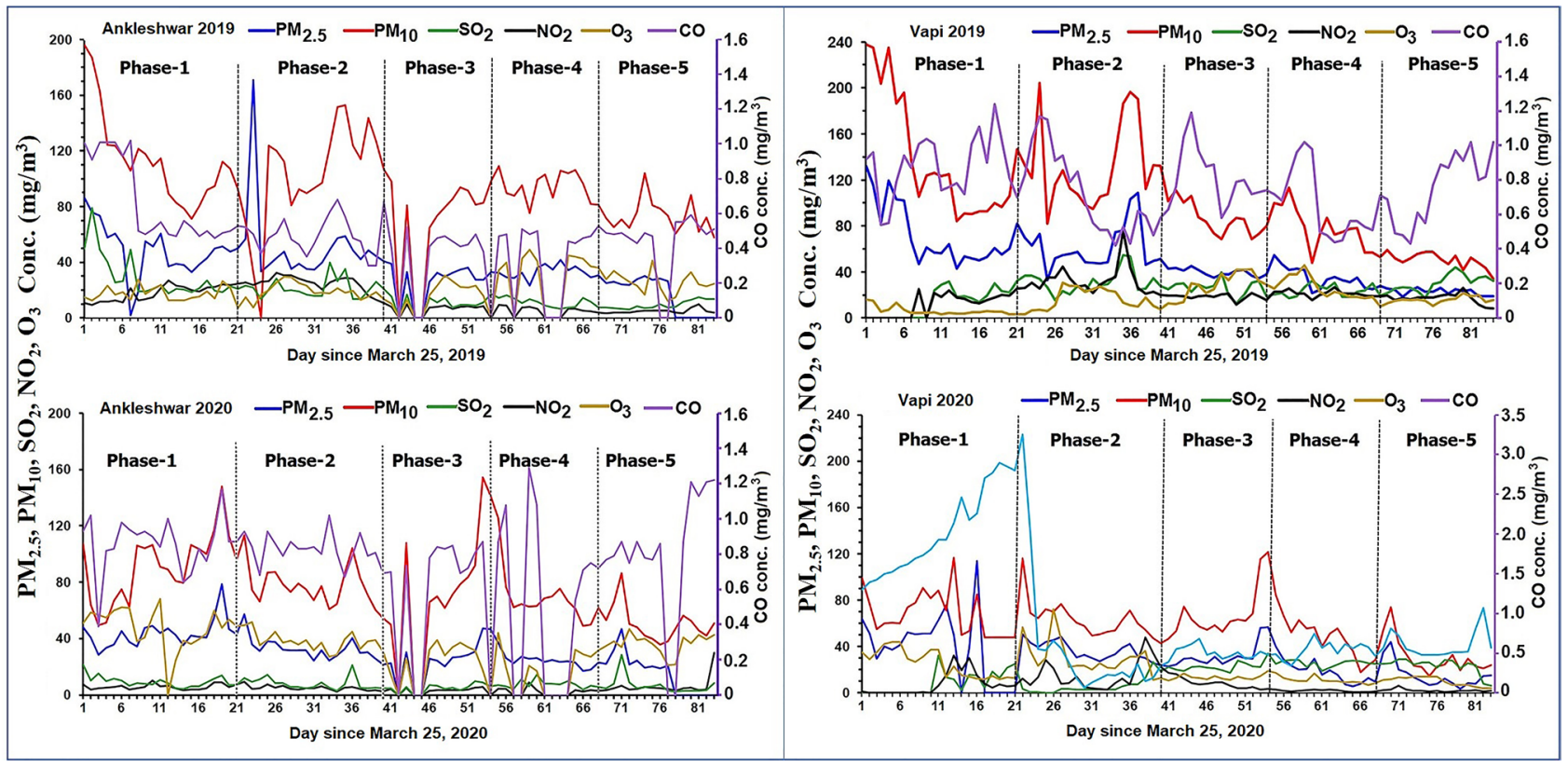

Figure 3. Mean concentrations of air pollutants from March 25 to June 15 for the year 2019 and 2020 for Ankleshwar and Vapi.

\begin{tabular}{|c|c|c|c|c|c|c|c|c|c|c|c|c|}
\hline \multirow[b]{2}{*}{ Period } & \multicolumn{2}{|l|}{$\mathbf{P M}_{2.5}$} & \multicolumn{2}{|l|}{$\mathrm{PM}_{10}$} & \multicolumn{2}{|l|}{$\mathrm{SO}_{2}$} & \multicolumn{2}{|l|}{$\mathrm{O}_{3}$} & \multicolumn{2}{|l|}{$\mathrm{CO}$} & \multicolumn{2}{|l|}{$\mathrm{NO}_{2}$} \\
\hline & \begin{tabular}{|l|} 
Mean diff \\
$(\%)$
\end{tabular} & SD diff (\%) & $\begin{array}{l}\text { Mean diff } \\
(\%)\end{array}$ & SD diff (\%) & $\begin{array}{l}\text { Mean diff } \\
(\%)\end{array}$ & SD diff $(\%)$ & $\begin{array}{l}\text { Mean diff } \\
(\%)\end{array}$ & SD diff (\%) & $\begin{array}{l}\text { Mean diff } \\
(\%)\end{array}$ & SD diff $(\%)$ & $\begin{array}{l}\text { Mean diff } \\
(\%)\end{array}$ & SD diff $(\%)$ \\
\hline \multicolumn{13}{|c|}{ Ankleshwar } \\
\hline Phase-1 & -10 & -46 & -19 & -30 & -67 & -75 & 192 & 113 & 30 & -35 & -67 & -67 \\
\hline Phase-2 & -36 & -74 & -29 & -50 & -63 & -38 & 98 & 20 & 74 & -20 & -80 & -71 \\
\hline Phase-3 & -6 & 131 & 5 & 231 & -54 & -51 & 44 & 35 & 84 & 100 & -50 & 33 \\
\hline Phase-4 & -26 & -3 & -27 & 67 & -30 & -16 & -31 & 86 & 91 & 243 & -37 & 5 \\
\hline Phase-5 & -5 & 335 & 24 & 11 & -28 & 123 & 44 & -1 & 150 & -99 & 27 & 35 \\
\hline \multicolumn{13}{|l|}{ Vapi } \\
\hline Phase-1 & -25 & -24 & -51 & -54 & -32 & -16 & 310 & 215 & 132 & 194 & -43 & -38 \\
\hline Phase-2 & -40 & -59 & -52 & -56 & -81 & -30 & 83 & 64 & -22 & 225 & -53 & -4 \\
\hline Phase-3 & -19 & 223 & -21 & 62 & -12 & -39 & -53 & -79 & -38 & -56 & -55 & 81 \\
\hline Phase-4 & -48 & 4 & -38 & -1 & 7 & -45 & -59 & -68 & -18 & -50 & -91 & -70 \\
\hline Phase-5 & -35 & 260 & -36 & 135 & -24 & -9 & -36 & 30 & -20 & -105 & -86 & -71 \\
\hline
\end{tabular}

Table 2. Mean difference and standard deviation difference (rounded up for clarity) observed during different lockdown phases of 2020 in comparison to the same period in 2019 for Ankleshwar and Vapi cities.

available at cpcb.nic.in which is maintained by the Ministry of Environment, Forest and Climate Change, Government of India ${ }^{40}$. The Meta-analysis of continuous data was performed using descriptive and inferential statistical techniques to determine the number of variations (reduction or increase) in the air pollutant levels during the different phases, to calculate the mean differences. Additionally, standard deviation was also computed to determine the fluctuation of air pollutants during different periods. Each air pollutant's mean differences during different phases for both the cities were compared to determine the impact of lockdown restrictions at two different geographical locations with similar economic characteristics. Lastly, a linear regression analysis was performed to determine the relationship of the AQI values with the different lockdown phases.

\section{Results}

The mean distribution of air pollutants during lockdown for COVID-19 and a similar period in 2019 for the two cities is shown in (Fig. 3 and Table 2). The phase-wise percentage variation of the mean and standard deviation of pollutants for both cities during the lockdown is shown in Table 3. In Ankleshwar, the maximum decline was observed in $\mathrm{NO}_{2}(80 \%)$ during phase-2, while in Vapi the maximum drop was also in $\mathrm{NO}_{2}(91 \%)$ during phase-4 of lockdown. $\mathrm{O}_{3}$ increased by $192 \%$ and $310 \%$ in Ankleshwar and Vapi, respectively during phase- $1 . \mathrm{SO}_{2}$ declined by $-67 \%$ during phase- 1 and rose to $-28 \%$ during unlock 1.0 in Ankleshwar but it dropped to a maximum of $81 \%$ during phase-2, followed by an increase to more than $7 \%$ in comparison to the 2019 period during phase- 4 


\begin{tabular}{|c|c|c|c|c|c|c|c|c|c|c|c|c|c|c|c|c|c|c|c|c|}
\hline \multirow[b]{2}{*}{ Pollutant } & \multicolumn{4}{|c|}{ Phase 1 (Lockdown 1.0) } & \multicolumn{4}{|c|}{ Phase 2 (Lockdown 2.0) } & \multicolumn{4}{|c|}{ Phase 3 (Lockdown 3.0) } & \multicolumn{4}{|c|}{ Phase 4 (Lockdown 4.0) } & \multicolumn{4}{|c|}{ Phase 5 (Unlock 1.0) } \\
\hline & Mean & Min & $\operatorname{Max}$ & SD & Mean & Min & $\operatorname{Max}$ & SD & Mean & Min & $\operatorname{Max}$ & SD & Mean & Min & Max & SD & Mean & Min & Max & SD \\
\hline \multicolumn{21}{|c|}{ ANKLESWAR 2019} \\
\hline PM 2.5 & 48.670 & 1.870 & 86.410 & 18.750 & 50.731 & 33.470 & 171.000 & 30.138 & 31.881 & 25.780 & 38.800 & 3.995 & 32.943 & 23.070 & 41.660 & 4.751 & 26.482 & 23.870 & 30.060 & 2.076 \\
\hline PM 10 & 113.345 & 71.150 & 196.290 & 33.193 & 108.501 & 32.290 & 152.900 & 30.094 & 84.567 & 64.690 & 98.580 & 10.417 & 94.401 & 75.380 & 109.080 & 10.738 & 72.949 & 57.930 & 104.070 & 11.814 \\
\hline NO & 18.015 & 9.230 & 26.670 & 5.690 & 24.689 & 10.610 & 32.590 & 5.892 & 8.139 & 6.680 & 9.710 & 0.823 & 6.732 & 3.790 & 9.340 & 1.762 & 4.882 & 3.130 & 9.890 & 1.748 \\
\hline $\mathrm{SO}_{2}$ & 28.995 & 17.500 & 79.250 & 15.707 & 21.488 & 13.370 & 39.670 & 7.089 & 12.310 & 7.550 & 16.990 & 3.354 & 10.843 & 6.400 & 16.220 & 3.246 & 9.448 & 6.140 & 14.870 & 2.990 \\
\hline $\mathrm{CO}$ & 0.663 & 0.460 & 1.020 & 0.236 & 0.479 & 0.300 & 0.680 & 0.110 & 0.439 & 0.380 & 0.520 & 0.043 & 0.477 & 0.430 & 0.530 & 0.031 & 0.502 & 0.430 & 0.590 & 0.043 \\
\hline OZONE & 17.113 & 6.920 & 27.880 & 5.245 & 19.184 & 7.640 & 29.740 & 5.582 & 20.302 & 10.090 & 30.680 & 6.317 & 41.095 & 34.490 & 48.970 & 4.418 & 25.217 & 11.990 & 41.370 & 7.538 \\
\hline \multicolumn{21}{|c|}{ ANKLESWAR 2020} \\
\hline PM 2.5 & 43.694 & 28.540 & 78.540 & 10.112 & 32.439 & 21.610 & 57.280 & 7.735 & 30.107 & 20.230 & 47.270 & 8.919 & 24.424 & 16.970 & 37.110 & 4.615 & 25.259 & 19.140 & 46.790 & 9.012 \\
\hline PM 10 & 91.413 & 49.380 & 148.190 & 24.285 & 77.031 & 54.560 & 113.200 & 14.617 & 88.775 & 50.010 & 154.230 & 33.151 & 68.518 & 49.130 & 125.690 & 18.244 & 50.338 & 35.800 & 86.550 & 12.659 \\
\hline NO & 5.849 & 3.400 & 10.410 & 1.887 & 4.894 & 2.540 & 9.150 & 1.669 & 4.066 & 2.980 & 5.500 & 1.042 & 4.166 & 2.640 & 9.000 & 2.028 & 6.219 & 3.150 & 29.760 & 6.582 \\
\hline $\mathrm{SO}_{2}$ & 9.434 & 4.370 & 21.900 & 3.972 & 7.986 & 2.890 & 21.250 & 4.383 & 6.138 & 3.360 & 9.760 & 1.930 & 7.567 & 4.050 & 14.340 & 2.711 & 6.646 & 2.440 & 28.480 & 6.439 \\
\hline $\mathrm{CO}$ & 0.861 & 0.390 & 1.170 & 0.157 & 0.826 & 0.670 & 1.020 & 0.088 & 0.782 & 0.690 & 0.870 & 0.067 & 0.880 & 0.540 & 1.290 & 0.249 & 1.251 & 0.750 & 5.380 & 1.252 \\
\hline OZONE & 50.023 & 24.530 & 68.360 & 11.155 & 37.945 & 27.080 & 51.960 & 6.544 & 29.428 & 14.270 & 39.050 & 8.082 & 27.741 & 16.970 & 44.140 & 8.762 & 36.327 & 21.160 & 46.690 & 7.189 \\
\hline \multicolumn{21}{|c|}{ VAPI 2019} \\
\hline PM 2.5 & 72.230 & 42.780 & 132.080 & 26.584 & 61.099 & 33.020 & 108.700 & 19.346 & 39.774 & 34.370 & 45.260 & 3.308 & 35.334 & 21.940 & 54.810 & 9.504 & 23.391 & 18.120 & 27.700 & 2.975 \\
\hline PM 10 & 139.818 & 84.190 & 238.000 & 53.067 & 131.908 & 82.210 & 204.250 & 36.470 & 86.347 & 68.580 & 111.150 & 13.842 & 79.172 & 48.040 & 113.300 & 18.160 & 51.563 & 41.650 & 59.060 & 5.076 \\
\hline NO & 23.396 & 13.730 & 32.330 & 6.203 & 31.212 & 15.780 & 54.420 & 9.916 & 25.991 & 12.640 & 39.550 & 6.787 & 23.904 & 17.190 & 32.440 & 5.066 & 29.682 & 17.260 & 44.210 & 7.869 \\
\hline $\mathrm{SO}_{2}$ & 19.142 & 12.890 & 25.580 & 4.045 & 32.505 & 19.910 & 76.030 & 12.663 & 18.468 & 11.810 & 21.470 & 2.487 & 21.428 & 15.480 & 26.590 & 2.745 & 17.591 & 9.020 & 26.150 & 3.876 \\
\hline $\mathrm{CO}$ & 0.878 & 0.540 & 1.240 & 0.178 & 0.714 & 0.420 & 1.170 & 0.241 & 0.813 & 0.580 & 1.190 & 0.169 & 0.658 & 0.440 & 1.020 & 0.208 & 0.734 & 0.430 & 1.020 & 0.188 \\
\hline OZONE & 6.216 & 3.130 & 15.950 & 3.785 & 16.535 & 3.580 & 30.890 & 9.011 & 28.796 & 12.410 & 42.300 & 10.593 & 26.639 & 17.400 & 45.920 & 9.252 & 15.531 & 10.270 & 21.530 & 3.146 \\
\hline \multicolumn{21}{|l|}{ VAPI 2020} \\
\hline PM 2.5 & 43.694 & 28.540 & 78.540 & 10.112 & 32.439 & 21.610 & 57.280 & 7.735 & 30.107 & 20.230 & 47.270 & 8.919 & 24.424 & 16.970 & 37.110 & 4.615 & 25.259 & 19.140 & 46.790 & 9.012 \\
\hline PM 10 & 91.413 & 49.380 & 148.190 & 24.285 & 77.031 & 54.560 & 113.200 & 14.617 & 88.775 & 50.010 & 154.230 & 33.151 & 68.518 & 49.130 & 125.690 & 18.244 & 50.338 & 35.800 & 86.550 & 12.659 \\
\hline NO & 5.849 & 3.400 & 10.410 & 1.887 & 4.894 & 2.540 & 9.150 & 1.669 & 4.066 & 2.980 & 5.500 & 1.042 & 4.166 & 2.640 & 9.000 & 2.028 & 6.219 & 3.150 & 29.760 & 6.582 \\
\hline $\mathrm{SO}_{2}$ & 9.434 & 4.370 & 21.900 & 3.972 & 7.986 & 2.890 & 21.250 & 4.383 & 6.138 & 3.360 & 9.760 & 1.930 & 7.567 & 4.050 & 14.340 & 2.711 & 6.646 & 2.440 & 28.480 & 6.439 \\
\hline $\mathrm{CO}$ & 0.861 & 0.390 & 1.170 & 0.157 & 0.826 & 0.670 & 1.020 & 0.088 & 0.782 & 0.690 & 0.870 & 0.067 & 0.880 & 0.540 & 1.290 & 0.249 & 1.251 & 0.750 & 5.380 & 1.252 \\
\hline OZONE & 50.023 & 24.530 & 68.360 & 11.155 & 37.945 & 27.080 & 51.960 & 6.544 & 29.428 & 14.270 & 39.050 & 8.082 & 27.741 & 16.970 & 44.140 & 8.762 & 36.327 & 21.160 & 46.690 & 7.189 \\
\hline
\end{tabular}

Table 3. Variation air pollutant concentrations for pre-COVID19 (2019) and COVID19 (2020) years. All pollutants are in units of $\mu \mathrm{g} / \mathrm{m}^{3}$ and CO is expressed in units of $\mathrm{mg} / \mathrm{m}^{3}$. Min minimum, Max maximum, $S D$ standard deviation.

in Vapi. $\mathrm{PM}_{2.5}$ ranged between - 36 and - 5\% during phase-2 and phase-5, respectively in Ankleshwar. While in Vapi it ranged between -48 and $-19 \%$ in phase- 4 and phase- 3 , respectively. $\mathrm{PM}_{10}$ also showed a similar trend but it did not decline below 29\% and 52\% during phase-2 in Ankleshwar and Vapi, respectively. CO continued to increase in Ankleshwar from 30\% in phase-1 to $150 \%$ in phase-5 (unlock 1.0), while in Vapi it had varied from $132 \%$ in phase- 1 to $-38 \%$ in phase- 3 .

The linear correlations of metadata of each pollutant and linear regression between pollutant concentrations and lockdown days are shown in the matrix plot (Fig. 4) and regression plot (Fig. 5) respectively. A declining trend is observed in particulate matter $\left(\mathrm{PM}_{2.5}\right.$ and $\left.\mathrm{PM}_{10}\right), \mathrm{SO}_{2}$, and $\mathrm{NO}_{2}$ levels during the COVID-19 lockdown period, as compared to the pre-COVID-19 year (Table 1). The $\mathrm{O}_{3}$ concentration increased during the lockdown period compared to the pre-lockdown due to a decrease in $\mathrm{NO}_{2}$ content. The distribution of CO shows a variable trend. A scatter plot matrix (Fig. 4), a grid (or matrix) of scatter plots, a graphical equivalent of the correlation matrix, is used to assess air pollutant variable data and to visualize the bivariate relationships between combinations of variables of pre-COVID19 (2019) to COVID19 (2020) in both cities. Each scatter plot in the matrix visualizes the relationship between a pair of variables, allowing many relationships between several pairs of all air pollutant variables to be explored at once. The Matrix of scatter plot (Fig. 4) clearly shows the variable distribution of the pollutant variables from pre-COVID19 (2019) and COVID19 lockdown period (2020) in all combination of scatter plots. It is also clearly observable from Matrix plot, a positive correlation between particulate matter $\left(\mathrm{PM}_{2.5}\right.$ and $\left.\mathrm{PM}_{10}\right)$ with $\mathrm{NO}_{2}, \mathrm{SO}_{2}$, and $\mathrm{CO} . \mathrm{O}_{3}$ shows a negative correlation with particulate matter $\left(\mathrm{PM}_{2.5}\right.$ and $\left.\mathrm{PM}_{10}\right), \mathrm{SO}_{2}$ and $\mathrm{NO}_{2}$.

Further, we also note that the linear regression analysis exhibited a negative correlation between the daily AQI and the growing number of lockdown days (Fig. 5). The main reason behind the negative correlation could be the meteorological conditions prevailing in the region. In South Gujarat region during 2020 and 2019 a southerly gentle breeze with a speed of $2-4 \mathrm{~m} \mathrm{~s}^{-1}$ prevailed ${ }^{23}$ combined with the closure of transport and industries for a longer continuous period in comparison to the similar pre-COVID-19 period ${ }^{41}$. We believe that the prevalence of consistent wind speed and direction in the South Gujarat region during the 2020 lockdown and similar period of 2019 (along with different restrictions imposed during the lockdown in 2020) has helped in reducing pollutant levels.

The results of the present study corroborates with other recent similar studies conducted in various cities across the globe (USA ${ }^{3}$; China ${ }^{12,13,15}$; Brazil ${ }^{16}$; Italy $^{42}$ India $^{23}$ ). 


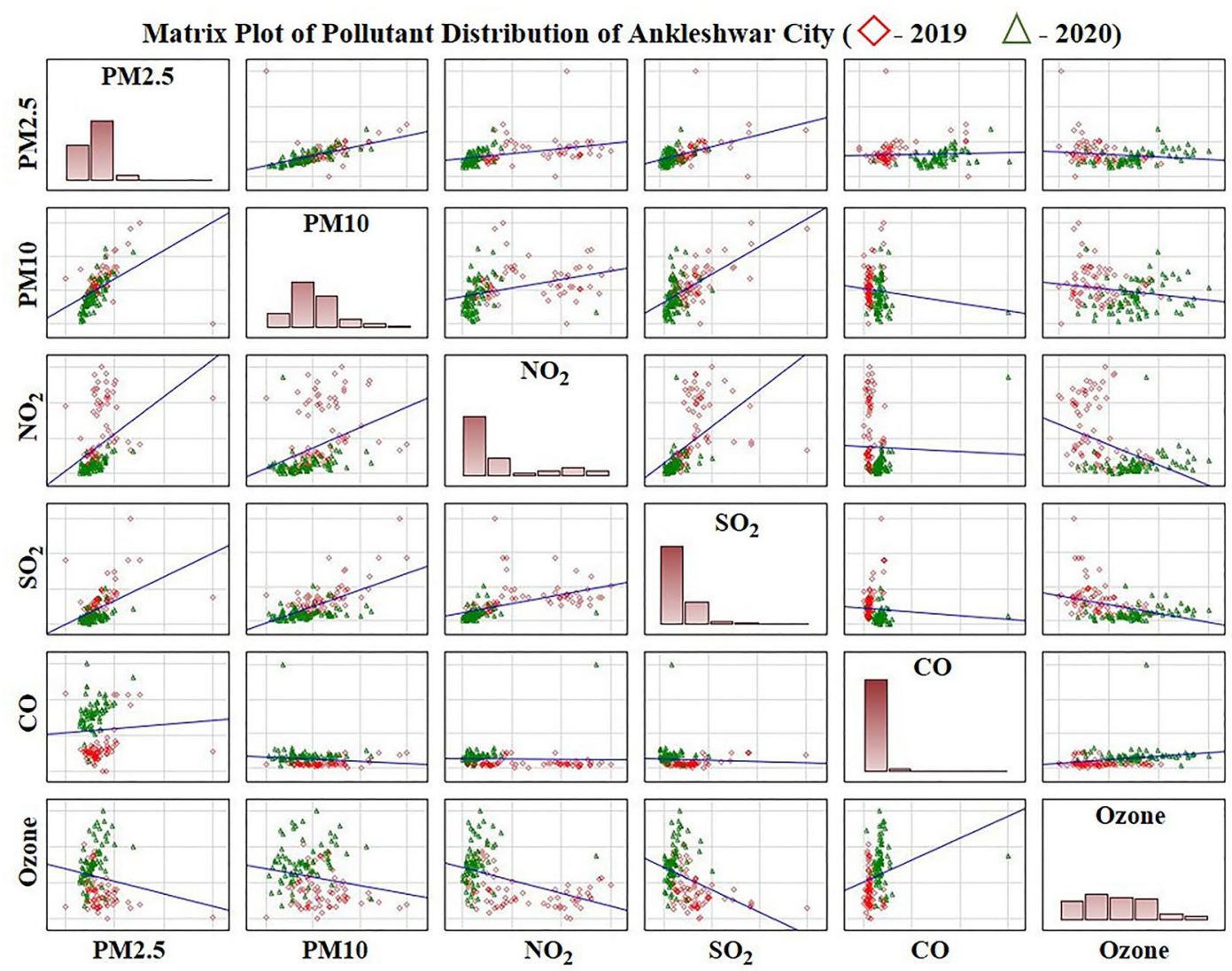

Matrix Plot of Pollutant Distribution of Vapi City $(\diamond-2019 \triangle-2020)$
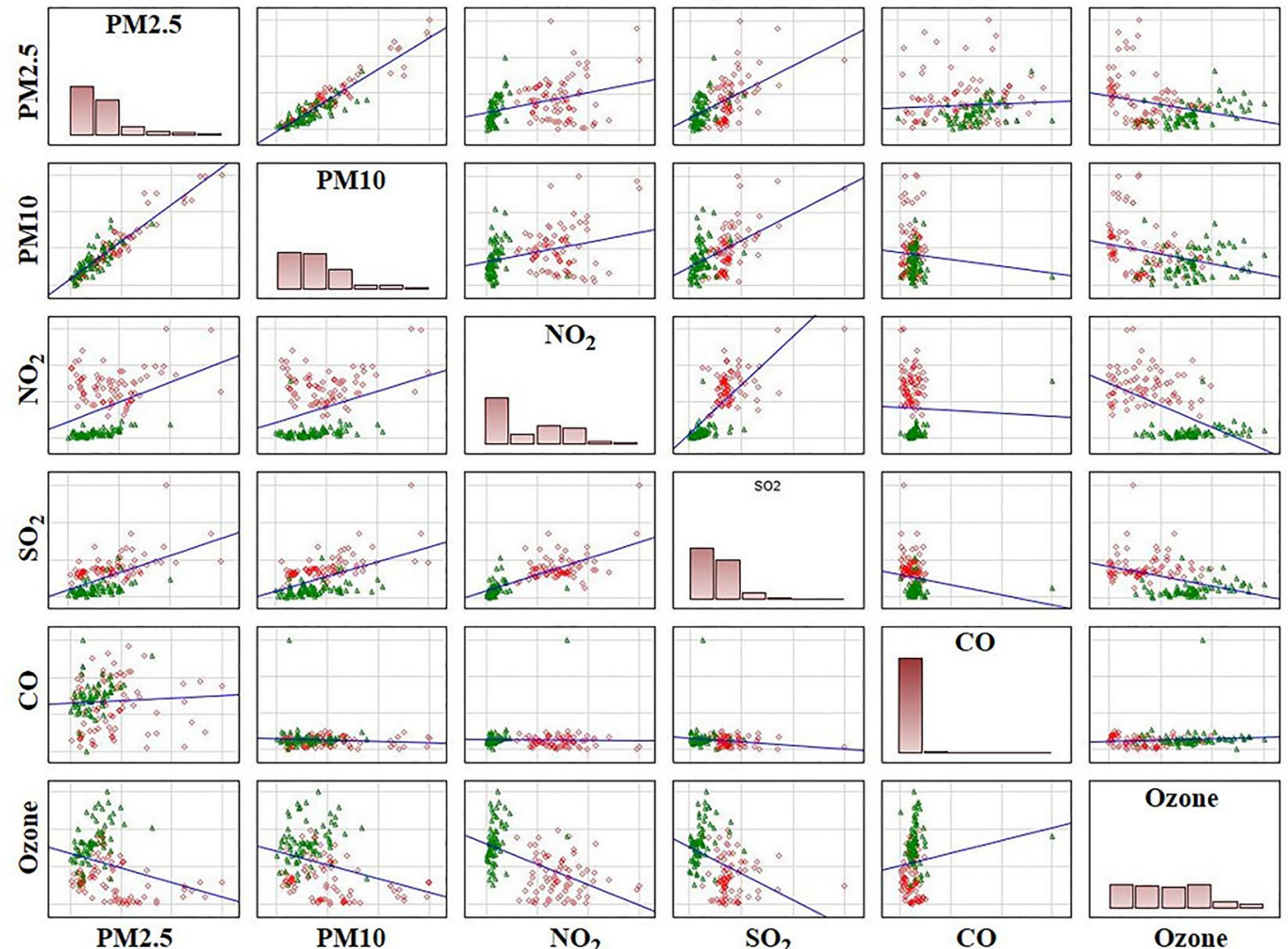

PM2.5

PM10
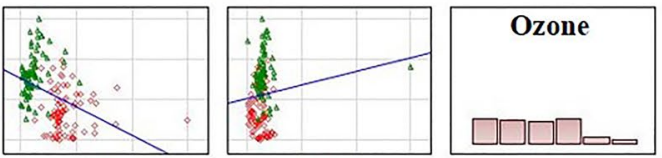

Figure 4. Correlation matrix scatter plot of the air pollutants (The Diagonal Bar Diagrams are the density plots fo various pollutant variables showing the distribution of data). 

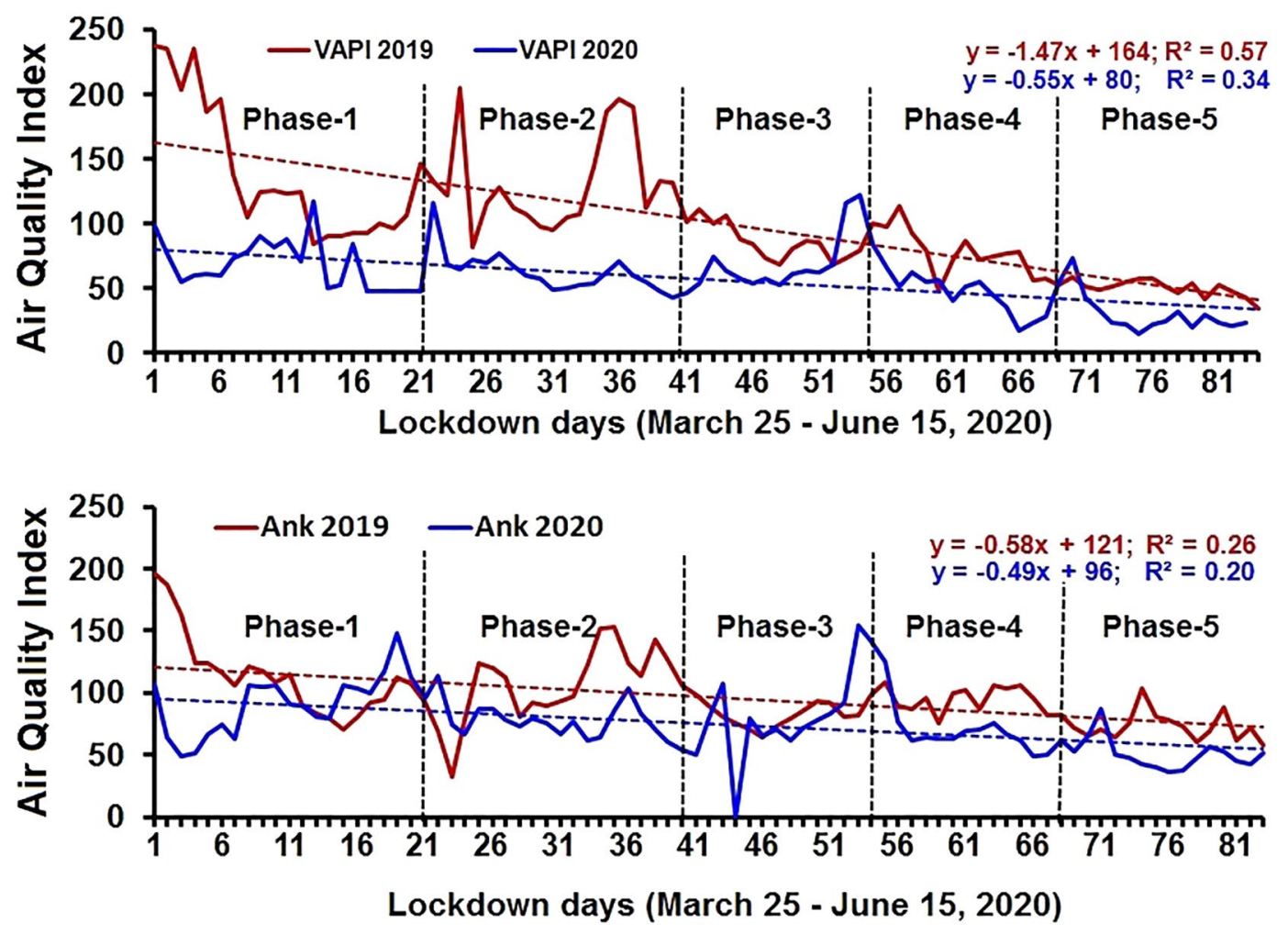

Figure 5. Linear regression of AQI for Vapi and Ankleshwar for 2019 and 2020.

\section{Discussion}

Environmental degradation due to anthropogenic pollution has become a chronic problem the world over. In India, haphazard development has led to various problems such as land degradation and air-water quality degradation, mainly in urban areas. Air pollution has become a severe problem in various metropolitan cities and industrialized centers across the country. Incomplete combustion of fossil fuels by vehicles and industrial operations $s^{42}$, and improper disposal of anthropogenic waste are the root causes of the rapid increases in air pollution. In March 2020, the COVID-19 pandemic led to a nationwide lockdown to control the spread of infection. The total stretch of various phases of lockdown was 68 days, in which the restrictions were eased subsequently. Although temporarily, the long stretch of restrictions on economic activities provided an opportunity for the environment to heal itself from the continuous exploitation by human activities ${ }^{8}$.

It is evident from the recent studies that reductions in most of the pollutants was observed all over India during the lockdown period. In a study across 12 cities, located in different spatial segments Indo-Gangetic Plain (IGP), showed a substantial decrease (35\%) of PM2.5 concentrations across the cities located in IGP after implementation of lockdown ${ }^{43}$. In Saurashtra and South Gujarat regions in Gujarat state, reductions up to 30-84\% in $\mathrm{NO}_{2}$ concentration was observed, while $\mathrm{O}_{3}$ increased by $16-48 \%$ due to reduction in $\mathrm{NO}_{2}$. The average decrease in AQI values of $58 \%$ was mainly observed in industrial cities such as Ahmedabad, Gandhinagar, Jamnagar, and Rajkot ${ }^{32}$. The atmospheric pollution level (NO2, PM2.5, and PM10) in Ahmedabad city also showed a significant improvement during the study period, implying a positive response of COVID-19 imposed lockdown on the environmental front ${ }^{44}$. In Delhi, the pollutant level came down to its 5-year low during the first week of lockdown phase-1, where $\mathrm{PM}_{2.5}$ concentration dropped to $42 \mu \mathrm{g} / \mathrm{m}^{3}$ (similar to the values observed in March $2016)^{45}$. AQI reduction in Delhi was $49 \%$ compared to the previous year, thus improvement of about $60 \%$ was mainly observed in the industrial and transport hub ${ }^{33}$. During the lockdown period, reduction in $\mathrm{PM}_{2.5}$ among all the pollutants was maximum in Gaya, Kanpur, Nagpur, and Kolkata ${ }^{23}$. The results of the study ${ }^{46}$ of variation in ambient air quality during COVID-19 lockdown in Chandigarh showed significant reductions in all air pollutants during the first and second phases of the Lockdown. The concentration of PM10, PM2.5, NO2 and SO2 reduced by $55 \%, 49 \%, 60 \%$ and $19 \%$, and $44 \%, 37 \%, 78 \%$ and $39 \%$ for Delhi and Mumbai, respectively, during post-lockdown phase leading to a significant improvement in air quality ${ }^{47}$. The reduction in mean concentration from the pre-lockdown phase to during lockdown of the main air pollutants is observed in Kolkatta City ${ }^{48}$. In a similar study ${ }^{49}$, on 16 cities designated as Hotspot region covering almost two thirds of India, also reported a significant reduction in the observed (mean) levels of PM10, PM2.5 and NO2 concentration during the lockdown period from March 25 to April 25.

The present study to assess the effect of COVID-19 lockdown in reducing air pollution in the two industrial cities viz., Ankleshwar and Vapi, Gujarat, India substantiate earlier studies. In comparison to a similar period in 2019, Ankleshwar observed a reduction in $\mathrm{PM}_{10}$ (primarily emitted by vehicles) and $\mathrm{PM}_{2.5}$ (caused by dust, ash, etc. $)^{39}$ concentrations during phase-1, while in Vapi the concentrations were reduced to almost half of those in 


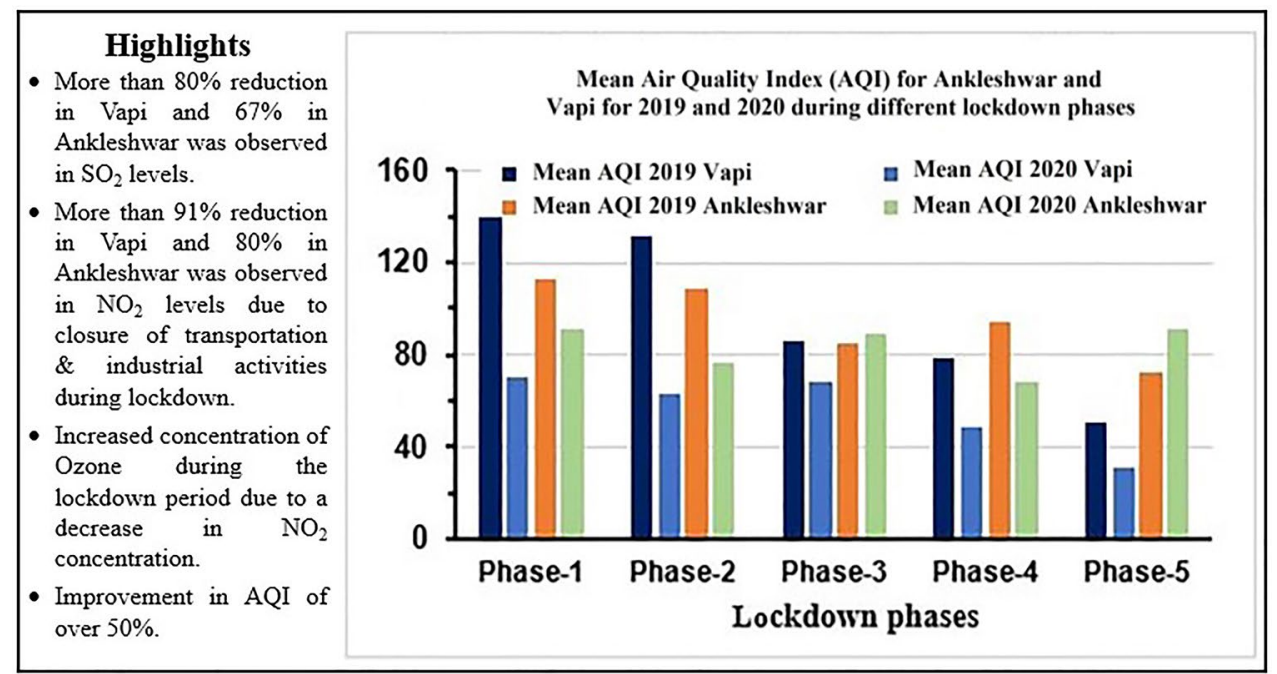

Figure 6. Mean Air Quality Index for Ankleshwar and Vapi for 2019 and 2020 during different lockdown phases.

the previous year (Fig. 3). The most plausible reason being the total restrictions on vehicular movements and industrial activities during the lockdown period. Similar drastically decreasing trends were observed for $\mathrm{SO}_{2}$ in Ankleshwar (highest reduction among all phases) produced by transportation and oil refineries ${ }^{50,51}$. Vapi also recorded a one-third reduction in its mean $\mathrm{SO}_{2}$ values.

Reduction in $\mathrm{NO}_{2}$, (which is emitted by heavy vehicles ${ }^{52}$ during all the phases consequently spiked the ozone concentration in both the cities (reduction in $\mathrm{NO}_{x}$ can increase ozone due to nonlinear relationships just above the ground level ${ }^{53}$ ). $\mathrm{CO}$, which is commonly produced by incomplete combustion of carbon-containing fuels ${ }^{54}$, showed rising trends in Ankleshwar during all the phases but dropped in Vapi.

Although rainfall, a significant determinant which helps to lower the pollutant levels occurred negligibly during the study period in both the cities, which implies that, in the absence of good amount of rainfall, which is a vital factor of pollution reduction, the difference in the trends is a result of continuous operation of the majority of pharmaceutical industries establishments in Ankleshwar during the lockdown. At the same time, Vapi showed a reduction in $\mathrm{CO}$ (except in phase-4 and phase-5) due to the non-operation of the majority of industries during the lockdown phase. Phase-2 lockdown continued for 14 days during which the $\mathrm{PM}_{2.5}$ along with $\mathrm{PM}_{10}, \mathrm{SO}_{2}$, and $\mathrm{NO}_{2}$ showed decreasing trends, whereas $\mathrm{SO}_{2}$ significantly dropped in all phases in both the cities (Table 2).

During phase-3, with restrictions eased, economic activities were restarted in a gradual manner, which led to the increasing trend in the pollutants. In Ankleshwar, during phase-4 (lockdown) and phase-5 (unlock-1), $\mathrm{PM}_{2.5}$ and $\mathrm{PM}_{10}$ mean concentrations exhibited an increasing trend due to increased vehicular movement and industrial operations, but Vapi still showed significant decreasing trends compared to 2019. The continuous operations of pharmaceutical industries during the lockdown phases, primarily the large-scale production 'Hydroxychloroquine' which is considered effective in COVID-19 treatment at Zydus Cadila, Vital Pharma and Mangalam Drugs and Organics located in Ankleshwar and Vapi, and its transportation to the seaports, is probably one of the main reasons for increases in vehicle-related pollutants ( $\mathrm{NOx}, \mathrm{SO}_{2}, \mathrm{CO}$ ) since mid-phase-3 due to its global demand. Which can further be verified from the statement "In Ankleshwar, Vatva and Vapi the major sectors contributing to air pollution were transport, industries and power plants" given by a senior Gujarat Pollution Control Board official (John, April 7, 2020). "Construction, road dust re-suspension, and residential activities also contributed to pollution. In addition landfill fires, operation of DG sets, cooking at restaurants also added to pollution" 55 .

Concurrently, it is evident from the negative correlation between air quality index values of Ankleshwar and Vapi and COVID-19 lockdown days (Fig. 5) that the majority of air pollutants decreased since March 25, 2020 as the lockdown period got extended in a phased manner. The most obvious reason was the shutting down of the industrial and transport sector since the lockdown phase- 1 started and as the days progressed, pollutants were subsequently flushed out ${ }^{40}$.

However, different trends of some pollutants (minimal increment during later phases) are probably due to two primary causes. First, the diversity in the industrial setup and decline in the number of the on-road vehicle ${ }^{3,56}$. Ankleshwar hosts the majority of pharmaceutical manufacturing plants, while Vapi houses more heterogeneous industries, such as pharmaceutical, petrochemical, etc. This difference indirectly influences the emission of different pollutants (as per the raw material used for the processing) and the transportation of the finished products to the market.

Secondly, and more importantly, the proximity of Vapi to the Arabian coast $(8 \mathrm{~km})$ is significantly lesser than Ankleshwar $(38 \mathrm{~km})$, which also plays a vital role in mixing up and higher fluctuation of pollutant range (due to sea-land breeze) in comparison to Ankleshwar. These causes suggest the differences in the rate of reduction and increment of the concentration of pollutants in the two cities. Figure 6 presents a summary of highlights and the variation in the Air Quality Index (AQI) corresponding to different lockdown phases. 


\section{Conclusion}

It is undoubtedly evidenced from this study and the others in several cities ${ }^{57}$, that the lockdown measures imposed to contain the spread of COVID-19 infection was found to be very effective resulting in a positive impact during the Pandemic as a blessing in disguise. It not only restricted the spread of infection rate, but also has given a scope to realize the restoration ability of environment and health with reduced ambient air pollutants levels leading to improved air quality.

The bold decision to impose strict lockdown measures by the Government of India despite economic losses, on the positive front, these measures brought significant improvement in air quality. The present study takes into consideration of the air pollutant observation of all the 5 phases of lockdown period, in contrast to the earlier studies from different parts of the country, that are restricted to only the earlier phases of lockdown period, supports the improved air quality due to lockdown measures. This study highlights the air quality index data of two industrialized cities Ankleshwar and Vapi to determine the trends of different pollutants during all the lockdown phases of COVID-19 in India. Both cities have been classified as critically polluted in Gujarat during the last decade ${ }^{58}$. However, the present study showed a drastic overall reduction of pollutants in both the cities. The results revealed different patterns of gradual to a rapid reduction in most of the pollutant concentrations additionally an increment in $\mathrm{O}_{3}$ concentration due to drastic reduction in $\mathrm{NO}_{2}$ by as much as $80.18 \%$. Increases in other pollutants were also observed as the restrictions were eased during phase- 4 and unlock 1 .

The different lockdown phases were differentiated based on subsequent relaxation in the norms to restart economic activities. The world's largest lockdown event has provided an actual example instead of modeled scenarios to determine how the pollutants can fluctuate due to different economic restrictions. Due to fear of infection, individuals embraced the restrictions imposed by the lockdown. Thus, it allowed us to show the levels of reduction possible to curb pollution levels.

Although the meteorological conditions (specifically rainfall) could also play a role in bringing down the levels of air pollutions, however, the impact of rainfall is in very minimal in the present study area as no rainfall is reported during the studied duration. The impact of the meteorological conditions cannot be ignored and should be considered in the future for understanding the long term trends.

It is obvious that there is clear reduction in the pollutants levels due to COVID-19 related lockdown improving the air quality in most of parts of the earth as observed from the earlier studies and from the present study. The system imposed was certainly harsh for the economy. However, a modified mode of various reservations for the economy could be used to manage pollution levels on a case-to-case basis. The findings of the present study certainly offers potential scope to plan air pollution reduction strategies. For policymakers, the need for the hour is to acknowledge the role of lockdown in curbing air pollution and not to lose the lead unintentionally achieved during this period against rising air pollution to critical levels. It is hoped that the present situation will open the perspective of humans in understanding deleterious effects of anthropogenic activities.

\section{Data availability}

The Daily CPCB AQI data for more than 200 Indian stations as available open-source at https://app.cpcbccr.com/ ccr/\#/caaqm-dashboard-all/caaqm-landing.

Received: 20 October 2020; Accepted: 29 January 2021

Published online: 19 February 2021

\section{References}

1. WHO (World Health Organization). World Health Organization Emergency Dashboard. https://covid19.who.int/region/searo/ country/in. Accessed 8 July 2020 (2020)

2. Hu, B., Guo, H., Zhou, P. \& Zheng, L. S. Characteristics of SARS-CoV-2 and COVID-19. Nat. Rev. Microbiol. https://doi. org/10.1038/s41579-020-00459-7 (2020).

3. Chen, L. W. A., Chien, L. C., Li, Y. \& Lin, G. Nonuniform impacts of COVID-19 lockdown on air quality over the United States. Sci. Total Environ. https://doi.org/10.1016/j.scitotenv.2020.141105 (2020).

4. Berman, J. D. \& Ebisu, K. Changes in US air pollution during the COVID-19 pandemic. Sci. Total Environ. 739, 139864. https:// doi.org/10.1016/j.scitotenv.2020.139864 (2020) (ISSN 0048-9697).

5. Unnithan, P. S. G. Kerala reports first Coronavirus case in India. India Today News (Jan 30, 2020), India. https://www.indiatoday in/india/story/kerala-reports-first-confirmed-novel-coronavirus-case-in-india-1641593-2020-01-30 (2020).

6. MHA (Ministry of Home Affairs), Govt. of India. Circulars For Covid-19. https://www.mha.gov.in/notifications/circulars-covid $-19(2020)$

7. UNDP (United Nations Development Programme). Socio-Economic impact of COVID-19. https://www.undp.org/content/undp/ en/home/coronavirus/socio-economic-impact-of-covid-19.html. Accessed 8 July 2020 (2020).

8. Ndegwa, S. An environmental silver lining amid COVID-19 cloud. China Global Television Network, Opinion. Retrieved from https://news.cgtn.com/news/2020-06-06/An-environmental-silver-lining-amid-COVID-19-cloud-R4TpEvr0ty/index.html (2020).

9. He, G., Pan, Y. \& Tanaka, T. The short-term impacts of COVID-19 lockdown on urban air pollution in China. Nat. Sustain. https ://doi.org/10.1038/s41893-020-0581-y (2020).

10. Monserrate, M. A., Ruano, M. A. \& Alcalde, L. S. Indirect effects of COVID-19 on the environment. Sci. Total Environ. 728(2020), 138813. https://doi.org/10.1016/j.scitotenv.2020.138813 (2020).

11. European Environmental Agency. Air pollution goes down as Europe takes hard measures to combat. https://www.eea.europa.eu/ highlights/air-pollution-goes-down-as. Accessed 4 October 2020 (2020).

12. Nie, D. et al. Changes of air quality and its associated health and economic burden in 31 provincial capital cities in China during COVID-19 pandemic. Atmos. Res. https://doi.org/10.1016/j.atmosres.2020.105328 (2020).

13. Shi, X., \& Brasseur, G. P. The response in air quality to the reduction of Chinese economic activities during the COVID-19 outbreak. Geophysical Research Letters, 47, e2020GL088070. https://doi.org/https://doi.org/10.1029/2020GL088070 (2020).

14. Li, L. et al. Air quality changes during the COVID-19 lockdown over the Yangtze River Delta Region: An insight into the impact of human activity pattern changes on air pollution variation. Sci. Total Environ. https://doi.org/10.1016/j.scitotenv.2020.139282 (2020). 
15. Yuan, Q. et al. Spatiotemporal variations and reduction of air pollutants during the COVID-19 pandemic in a megacity of Yangtze River Delta in China. Sci. Total Environ. https://doi.org/10.1016/j.scitotenv.2020.141820 (2020).

16. Dantas, G., Siciliano, B., França, B., da Silva, C. M. \& Arbilla, G. The impact of COVID-19 partial lockdown on the air quality of the city of Rio de Janeiro. Brazil Sci. Total Environ. 729, 139085. https://doi.org/10.1016/j.scitotenv.2020.139085 (2020).

17. Siciliano, B. et al. The impact of COVID-19 partial lockdown on primary pollutant concentrations in the atmosphere of Rio de Janeiro and São Paulo Megacities (Brazil). Bull. Environ. Contam. Toxicol. 105, 2-8. https://doi.org/10.1007/s00128-020-02907-9 (2020).

18. Otmani, A. et al. Impact of COVID-19 lockdown on $\mathrm{PM} 10, \mathrm{SO}_{2}$ and $\mathrm{NO}_{2}$ concentrations in Salé City (Morocco). Sci. Total Environ. 735, 139541. https://doi.org/10.1016/j.scitotenv.2020.139541 (2020).

19. Tobías, C. et al. Changes in air quality during the lockdown in Barcelona (Spain) one month into the SARS-CoV-2 epidemic. Sci. Total Environ. 726(1-4), 2020. https://doi.org/10.1016/j.scitotenv.2020.138540 (2020).

20. Patel, K. Airborne nitrogen dioxide plummets over China. https://www.earthobservatory.nasa.gov/images/146362/airborne-nitro gen-dioxide-plummets-over-china. Accessed 4 October 2020 (2020).

21. Parker, H. A., Hasheminassab, S., Crounse, J. D., Roehl, C. M. \& Wennberg, P. O. Impacts of traffic reductions associated with COVID-19 on Southern California air quality. Geophys. Res. Lett. 47, e2020GL090164. https://doi.org/10.1029/2020GL090164 (2020).

22. Xu, L. et al. Variation in concentration and sources of black carbon in a megacity of China during the COVID-19 pandemic. Am. Geophys. Union. https://doi.org/10.1029/2020GL090444 (2020).

23. Sharma, S., Zhang, M., Gao, A., Zhang, H. \& Kota, S. H. Effect of restricted emissions during COVID-19 on air quality in India. Sci. Total Environ. 728, 138878. https://doi.org/10.1016/j.scitotenv.2020.138878 (2020).

24. Koken, P. J. et al. Temperature, air pollution and hospitalization for cardiovascular diseases among elderly people in Denver. Environ. Health Perspect. 111(10), 1312-1317 (2003).

25. LeTertre, A. et al. Short-term effects of particulate air pollution on cardiovascular diseases in eight European cities. J. Epidemiol. Community Health 56, 773-779 (2002).

26. Thorpe, A. J. \& Harrison, R. M. Sources and properties of non-exhaust particulate matter from road traffic: A review. Sci. Total Environ. 400, 270-282 (2020).

27. He, L. et al. On-road emission measurements of reactive nitrogen compounds from heavy duty diesel trucks in China. Environ. Pollut. 262, 114280 (2020).

28. Garaga, R., Sahu, S. K. \& Kota, S. H. A review of air quality modeling studies in India: local and regional scale. Curr. Pollut. Rep. 4(2018), 59-73 (2018).

29. Kota, S. H. et al. Year-long simulation of gaseous and particulate air pollutants in India. Atmos. Environ. 180, 244-255 (2018).

30. Mukherjee, M. \& Agrawal, A. Air pollutant levels are 12 times higher than guidelines in Varanasi, India. Sources Transf. Environ. Chem. Lett. 16(2018), 1009-1016 (2018).

31. MoEFC. Ministry of Environment, Forest and Climate change, Sundaray, S.N.K. \& Bharadwaj DSR (Eds.). National Clean Air Programme, New Delhi (2019).

32. Selvam, S. et al. SARS-CoV-2 pandemic lockdown: Effects on air quality in the industrialized Gujarat state of India. Sci. Total Environ. 737, 140391 (2020).

33. Mahato, S., Pal, S. \& Ghosh, K. G. Effect of lockdown amid COVID-19 pandemic on air quality of the megacity Delhi, India. Sci. Total Environ. https://doi.org/10.1016/j.scitotenv.2020.139086 (2020).

34. Sarella, G. \& Khambete, A. K. Ambient air quality analysis using air quality index-A case study of Vapi. Int. J. Innov. Res. Sci. Technol. 1(10), 2349-6010 (2015).

35. IMD (India Meteorological Department). Ministry of Earth Sciences, Government of India. Cumulative rainfall activity. https:// mausam.imd.gov.in/imd_latest/contents/cumulative_rainfall_activity.php (2020).

36. Vapi Green Enviro Limited. CETP Process Flow. http://www.vgelvapi.com/cetp-process-flow.html (2020).

37. Paliwal, A. Vapi tops list of critically polluted city. Down to Earth, News (May 21, 2012). https://www.downtoearth.org.in/news/ vapi-tops-list-of-critically-polluted-areas--38260 (2012).

38. Kambalagere, Y. A Study on Air Quality Index (AQI) of Bengaluru, Karnataka during Lockdown Period to Combat Coronavirus Disease (Covid-19): Air quality turns 'better' from 'hazardous'. Stud. Indian Place Names 40(69), 2394-3114 (2020).

39. National Air Quality Index - Report of the Expert Committee. Control of Urban Pollution Series (CUPS/82 /2014-15) - Central Pollution Control Board, Ministry of Environment, Forest and Climate Change, Government of India. https://app.cpcbccr.com/ ccr_docs/FINAL-REPORT_AQI_pdf (2014).

40. Central Control Room for Air Quality Management- All India. Continuous Stations Status, National Air Quality Index. Central Pollution Control Board, Ministry of Environment, Forest and Climate Change, Government of India. https://app.cpcbccr.com/ $\mathrm{ccr} / \# /$ caaqm-dashboard-all/caaqm-landing (2020).

41. The Hindu. Coronavirus lockdown lifts Delhi's March air quality to 5-year high. https://www.thehindu.com/news/cities/Delhi/ coronavirus-lockdown-lifts-delhis-march-air-quality-to-5-year-high/article31252221.ece. Accessed 24 December 2020. (2020)

42. Popescu, F. \& Lonel, I. Anthropogenic air pollution sources. Anthropogen. Air Pollut. Sources Air Qual. Ashok Kumar IntechOpen https://doi.org/10.5772/9751 (2010).

43. Das, M., Das, A. \& Mandal, A. Examining the impact of lockdown (due to COVID-19) on Domestic Violence (DV): An evidences from India. Asian J. Psychiatry https://doi.org/10.1016/j.ajp.2020.102335 (2020).

44. Aman, M. A., Salman, M. S. \& Ali, P. Y. COVID-19 and its impact on environment: Improved pollution levels during the lockdown period-A case from Ahmedabad. India. Remote Sens. Appl. Soc. Environ. https://doi.org/10.1016/j.rsase.2020.100382 (2020).

45. Jacob, K. Coronavirus lockdown lifts Delhi's air quality to 5-year high. The Hindu, News, Cities, Delhi (April 3, 2020). https:// www.thehindu.com/news/cities/Delhi/coronavirus-lockdown-lifts-delhis-march-air-quality-to-5-year-high/article31252221.ece (2020).

46. Mor, S. et al. Impact of COVID-19 lockdown on air quality in Chandigarh, India: understanding the emission sources during controlled anthropogenic activities. Chemosphere 263, 127978. https://doi.org/10.1016/j.chemosphere.2020.127978 (2020).

47. Kumari, P. \& Toshniwal, D. Impact of lockdown measures during COVID-19 on air quality-A case study of India. Int. J. Environ. Health Res. https://doi.org/10.1080/09603123.2020.1778646 (2020).

48. Sarkar, M., Das, A. \& Mukhopadhyay, S. Assessing the immediate impact of COVID-19 lockdown on the air quality of Kolkata and Howrah, West Bengal, India. Environ. Dev. Sustain. https://doi.org/10.1007/s10668-020-00985-7 (2020).

49. Garg, A., Kumar, A. \& Gupta, N. C. Impact of lockdown on ambient air quality in COVID-19 affected hotspot cities of India: Need to readdress air pollution mitigation policies. Environ. Claims J. 1, 65-76. https://doi.org/10.1080/10406026.2020.1822615 (2021).

50. Tripathi, A. K. \& Gautam, M. Biochemical parameters of plants as indicators of air pollution. J. Environ. Biol. 28, 127-132 (2007).

51. Chaudhary, A., Chaudhary, S. \& Sharma, Y. K. Study of plants in relation to ambient air quality in Lucknow city, Uttar Pradesh. Res. Environ. Life Sci. 1, 17-20 (2008).

52. USEPA (United Nations Development Programme). Socio-Economic impact of COVID-19. https://www.undp.org/content/undp/ en/home/coronavirus/socio-economic-impact-of-covid-19.html. Accessed 8 July 2020 (2020).

53. Sillman, S. The relation between ozone, NOx and hydrocarbons in urban and polluted rural environments. Atmos. Environ. 33(12), 1821-1845. https://doi.org/10.1016/S1352-2310(98)00345-8 (1999). 
54. Transportation Research Board and National Research Council. The Ongoing Challenge of Managing Carbon Monoxide Pollution in Fairbanks, Alaska: Interim Report. https://doi.org/10.17226/10378 (The National Academies Press, Washington, DC, 2002).

55. John, P. Lockdown: Off Ventilator, Gujarat's Industrial Zones Beat Gandhinagar AQI. Times of India, News, City news, Ahmedabad news. Retrieved from https://timesofindia.indiatimes.com/city/ahmedabad/lockdown-off-ventilator-gujarat-industrial-zones-beatgandhinagar-aqi/articleshow/75019420.cms (2020).

56. Giovanni, G. L., Carotenuto, F., Vagnoli, C., Zaldei, A. \& Gioli, B. Quantifying road traffic impact on air quality in urban areas: A Covid19-induced lockdown analysis in Italy. Environ. Pollut. 267, 115682. https://doi.org/10.1016/j.envpol.2020.115682 (2020).

57. Chen, S., Yang, J., Yang, W., Wang, C. \& Barnighausen, T. COVID-19 control in China during mass population movements at New Year. Lancet https://doi.org/10.1016/S0140-6736(20)30421-9 (2020).

58. TOI (Times of India). 'Pollution down in Vapi, Vatva and Ankleshwar. 'Pollution down in Vapi, Vatva and Ankleshwar'. https://times ofindia.indiatimes.com/city/ahmedabad/Pollution-down-in-Vapi-Vatva-and-Ankleshwar/articleshow/55643664.cms. Accessed 24 July 2020. (2016).

\section{Acknowledgements}

The first author (Mr. Ritwik Nigam) acknowledges the financial support provided by the University Grant Commission (UGC), Govt. of India, New Delhi, to conduct this research. The authors also thank the University Administration for their support.

\section{Author contributions}

R.N.: initial manuscript writing, methodology, formal analysis, writing the original draft. K.P.: visualization, prepared initial figures. A.J.L.: review and prepared figures. R.S.: review and editing. M.K.: review, editing, analysis, and interpretation.

\section{Competing interests}

The authors declare no competing interests.

\section{Additional information}

Correspondence and requests for materials should be addressed to M.K.

Reprints and permissions information is available at www.nature.com/reprints.

Publisher's note Springer Nature remains neutral with regard to jurisdictional claims in published maps and institutional affiliations.

(c) (i) Open Access This article is licensed under a Creative Commons Attribution 4.0 International

License, which permits use, sharing, adaptation, distribution and reproduction in any medium or format, as long as you give appropriate credit to the original author(s) and the source, provide a link to the Creative Commons licence, and indicate if changes were made. The images or other third party material in this article are included in the article's Creative Commons licence, unless indicated otherwise in a credit line to the material. If material is not included in the article's Creative Commons licence and your intended use is not permitted by statutory regulation or exceeds the permitted use, you will need to obtain permission directly from the copyright holder. To view a copy of this licence, visit http://creativecommons.org/licenses/by/4.0/.

(c) The Author(s) 2021 